\title{
Genetic Divergence Analysis in the Foxtail Millet (Seteria italica) Germplasm as Determined by Phenotypical Traits
}

\author{
R. Venkatesh*, N. Lakshmi Pallavi, B. Jalandar Ram and B. G. Suresh \\ Dept. of Genetics and Plant Breeding, SHUATS, Prayagraj, India \\ *Corresponding author
}

Ke y w o r d s
Foxtail millet
(Setaria italica
L.beauv), Genetic
advance,
Heritability,
D2 analysis
Article Info
Accepted:
10 November 2020
Available Online:
10 December 2020

\section{A B S T R A C T}

The present investigation was conducted to examine the genetic diversity among 40 genotypes of Foxtail millet, during kharif- 2019 under Randomized Block Design replicated thrice. The data were recorded for thirteen quantitative characters to obtain estimates of variability, heritability, genetic advance and genetic divergence. Significant differences were observed among the genotypes for all the characters studied. High estimates of GCV and PCV were observed for economic yield followed by harvest index and number of basal tillers. High heritability was recorded for number of basal tillers followed by biological yield. High genetic advance was recorded for days to $50 \%$ floweri ng followed by number of days to maturity. Mahalanobis D2 analysis revealed considerable amount of diversity in the material. The 40 genotypes were grouped into nine heterogenous clusters. Cluster - I had maximum number of 20 genotypes. On the basis of mean performance of the genotypes, ISE 1419 followed by ISE 90, ISE96 were found high for economic yield under Allahabad agro- climatic conditions. The characters such as harvest index, number of days to maturity, days to $50 \%$ flowering, flag leaf length showed high heritability coupled with moderate genetic advance. which indicates that there is more chance of inheritance from progeny to their offspring, therefore these characters should be given top priority for effective selection. The present investigation revealed that cluster $\mathrm{V}$ and VIII were most diverse. Genotypes constituted in these clusters may be used as parents for future hybridization.

\section{Introduction}

Foxtail millet (Setaria italica (L.) P. Beauv.] is one of the most economically important millet crops grown for grain, which is used for human consumption, animal, poultry, cage birds feeding and as fodder. The grain of foxtail millet is ovoid in shape, $2 \mathrm{~mm}$ long, yellow in colour enclosed by husk varying from pale yellow to orange, red, brown or black colour. Hence it should undergo de husking before processed for food (Brunda et al., 2017).

Foxtail millet is important minor millet belonging to the family poaceae. It is suited to conditions of low and moderate rainfall area due to early maturity period. Besides India, it is also grown in China, Russia, Japan, USA, other African and East Asian countries. In 
India, the cultivation of foxtail millet is confined to Andhra Pradesh, Karnataka, and Tamil Nadu.

The potentiality of foxtail millet is not yet exploited properly in India. The yield levels in China is $11 \mathrm{t} / \mathrm{ha}$, whereas in India it is just ranging between $0.4-0.8 \mathrm{t} / \mathrm{ha}$ suggesting a greater scope for exploitation of this millet under Indian conditions (Jiayju, 1996).

The study of growth analysis would help in understanding contributions of various growth processes in accumulation of dry matter and yield. The low yield in foxtail millet is generally attributed to genetic, physiological and agronomic factors. All the factors influencing growth and development of crop plants are to be integrated at an optimum level for maximum production potential. The present investigation was carried out to find out the variation in morphophysiological and their relationship with the productivity in foxtail millet genotypes. There is wide genetic diversity available in foxtail millet, and characterizing these resources is a prerequisite for the genetic improvement of its cultivars. In this article characterization of germplasm is done Brunda et al., (2017).

Foxtail millet grains are rich in protein, fibre, $\beta$ carotene, minerals viz., calcium, iron, potassium, magnesium, zinc, antioxidants and vitamins Rai (2002). The grains with husk intact have long shelf life which is a preferable attribute Ravi et al., (2010). Millet based dietary fiber, improves glycemic control, decreases hyperinsulinemia and lowers plasma lipid concentrations in patients with type 2 diabetes Jali et al., (201).

Foxtail millet grains are rich in protein, fibre, $\beta$ carotene, minerals viz., calcium, iron, potassium, magnesium, zinc, antioxidants and vitamins Rai (2002). The grains with husk intact have long shelf life which is a preferable attribute Ravi et al., (2010). Millet based dietary fiber, improves glycemic control, decreases hyperinsulinemia and lowers plasma lipid concentrations in patients with type 2 diabetes Jali et al., (201).

In 2015-16, total area under small millets was 1.79 mha with a production of $2.21 \mathrm{~m}$ tonnes at All India level. However, in Uttar Pradesh it covered 8000 ha with the production of 5000 tonnes and productivity of $625 \mathrm{~kg}$ per ha [Ministry of Agriculture and Farmers Welfare, Annual Progress Report, 2017-18.].

\section{Materials and Methods}

The present investigation was carried out at Field Experimentation Centre, Department of Genetics and Plant Breeding, Sam Higginbottom University of Agriculture, Technology and Science, Prayagraj, U.P. during Kharif -2019 . The experimental materials constituted 40 foxtail millet genotypes which is received from ICRISAT, Hyderabad. The experiment was laid out in the Randomized Block Design with three replication and has three rows with spacing of row to row $30 \mathrm{~cm}$ and plant to plant $10 \mathrm{~cm}$. The genotypes were sown by line sowing in each plot by imposing randomization in each replication.

Observation were recorded on days to $50 \%$ flowering, days to maturity, plant height $(\mathrm{cm})$, leaf length, leaf width, panicle length, inflorescence width, peduncle length, number of basal tillers, biological yield (g), harvest index $(\%)$, test weight $(\mathrm{g})$, grain yield per plant $(\mathrm{g})$.

The data were subjected to the analysis of variance (Fisher and Yates 1938) and further, biometrical procedures were followed to estimate genotypic and phenotypic coefficient of variation (Burton 1952), heritability in broad sense (Burton and Devane 1953), 
genetic advance (Johnson et al., 1955), genetic divergence (Mahalanobis D2 1936).

\section{Results and Discussion}

Analysis of variance showed highly significant differences among 40 Foxtail millet genotypes for all the characters under study, indicates that there is an ample scope for selection of promising genotypes from the present gene pool for yield improvement.

The estimates of genotypic variance (gcv) and phenotypic variance (pcv) were revealed that phenotypic variance was higher than genotypic variance for all the yield attributing characters indicating that the influence of environmental factors on these traits.

The magnitude of PCV and GCV was higher that for all 13 characters which indicates lesser role of environment on the expression of these characters. Highest differences between GCV and PCV were depicted for, plant height, peduncle length, panicle length.

Heritability ranged from $27.10 \%$ to $99.2 \%$. The high heritability was found in number of basal tillers followed by, biological yield, inflorescence width, grain yield, test weight, harvest index, leaf width, days to 50\% flowering and number of days to maturity, flag leaf length, peduncle length. While, moderate heritability was observed in panicle length and plant height.

Estimates of genetic advance revealed highest values for days to $50 \%$ flowering (23.26), number of days to maturity (23.20) and harvest index (21.83). Moderate values were observed in plant height (12.16) and flag leaf length (10.0). Lowest estimates of genetic advance were observed in panicle length (3.39), peduncle length (5.33), leaf width (0.49), number of basal tillers (5.83), inflorescence width (1.38), biological yield (4.18), grain yield (4.02) and test weigh (1.27) (Table 1-6).

Table.1 Analysis of Variance for 13 different quantitative parameters in Foxtail millet genotypes

\begin{tabular}{|c|c|c|c|c|}
\hline \multirow[b]{2}{*}{ S. No. } & \multirow[b]{2}{*}{ Characters } & \multicolumn{3}{|c|}{ Mean of sum square } \\
\hline & & $\begin{array}{c}\text { Replication } \\
\quad \text { df }=2\end{array}$ & $\begin{array}{c}\text { Treatme } \\
\text { nt df }=\end{array}$ & $\begin{array}{l}\text { Erro } \\
\mathbf{r} \text { df } \\
-70\end{array}$ \\
\hline 1. & Days to $50 \%$ flowering & 469.40 & $424.75 * *$ & 11.13 \\
\hline 2. & No. of Days to maturity & 441.45 & $426.54 * *$ & 12.20 \\
\hline 3. & Plant height $(\mathrm{cm})$ & 1344.97 & $7361.02 * *$ & 345.27 \\
\hline 4. & Panicle length (cm) & 5.12 & $22.93 * *$ & 6.04 \\
\hline 5. & Flag leaf length $(\mathrm{cm})$ & 27.75 & $102.63 * *$ & 9.71 \\
\hline 6. & Peduncle length $(\mathrm{cm})$ & 31.54 & $39.86 * *$ & 6.95 \\
\hline 7. & Leaf width $(\mathrm{cm})$ & 0.017 & $0.18 * *$ & 0.0028 \\
\hline 8. & No. of basal tillers & 0.0023 & $24.31 * *$ & 0.068 \\
\hline 9. & Inflorescence width $(\mathrm{cm})$ & 0.016 & $2.05 * *$ & 0.013 \\
\hline 10 & Biological yield (g) & 3.660333 & $12.60 * *$ & 0.05896 \\
\hline 11. & Test weight (g) & 0.449681 & $1.19 * *$ & 0.010869 \\
\hline 12. & Harvest index (\%) & 28.39013 & $352.38 * *$ & 3.965854 \\
\hline 13. & Grain yield (g) & 1.292966 & $11.789 * *$ & 0.079454 \\
\hline
\end{tabular}

$* *=$ Significance at $1 \%$ level of significance and $*=$ Significane at $5 \%$ level of significance 
Table.2 Estimation of genetic parameters for grain yield and other components

\begin{tabular}{|c|c|c|c|c|c|c|c|c|}
\hline S. No. & Characters & $\mathbf{V g}$ & $\mathbf{V p}$ & GCV & PCV & $\begin{array}{l}\text { h2\% (Broad } \\
\text { sense) }\end{array}$ & Genetic advance & $\begin{array}{c}\text { Genetic Advance as\% } \\
\text { of } \\
\text { Mean (GA \%M) }\end{array}$ \\
\hline 1. & Days to $50 \%$ flowering & 137.87 & 149 & 22.27 & 23.15 & 92.5 & 23.26 & 44.14 \\
\hline 2. & No. of Days to maturity & 138.11 & 150.31 & 13.69 & 14.28 & 91.9 & 23.20 & 27.04 \\
\hline 3. & Plant height $(\mathrm{cm})$ & 128.58 & 473.85 & 10.84 & 20.81 & 27.10 & 12.16 & 11.63 \\
\hline 4. & Panicle length $(\mathrm{cm})$ & 5.62 & 11.67 & 21.01 & 30.27 & 48.22 & 3.392 & 30.05 \\
\hline 5. & Flag leaf length $(\mathrm{cm})$ & 30.97 & 40.68 & 23.25 & 26.65 & 76.1 & 10.003 & 41.79 \\
\hline 6. & Peduncle length $(\mathrm{cm})$ & 10.97 & 17.92 & 34.61 & 44.24 & 61.22 & 5.33 & 55.79 \\
\hline 7. & Leaf width $(\mathrm{cm})$ & 0.059 & 0.062 & 26.43 & 27.05 & 95.4 & 0.49 & 53.19 \\
\hline 8. & No. of basal tillers & 8.082 & 8.15 & 43.86 & 44.04 & 99.2 & 5.83 & 89.97 \\
\hline 9. & Inflorescence width $(\mathrm{cm})$ & 0.68 & 0.69 & 43.33 & 43.76 & 98.1 & 1.68 & 88.40 \\
\hline 10 & Biological yield (g) & 4.18 & 4.24 & 14.27 & 14.37 & 98.6 & 4.184 & 29.19 \\
\hline 11. & Harvest index (\%) & 116.1 & 120 & 53.03 & 53.93 & 96.7 & 21.83 & 107.43 \\
\hline 12. & Test weight (g) & 0.39 & 0.40 & 34.421 & 34.89 & 97.3 & 1.27 & 69.95 \\
\hline 13. & Grain yield (g) & 3.90 & 3.98 & 64.60 & 65.25 & 98.00 & 4.02 & 131.74 \\
\hline
\end{tabular}

GCV = Genotypic Coefficient of Variation PCV = Phenotypic Coefficient of Variation

$\mathrm{H}^{2}=$ Heritability (broad sense)

Table.3 Distribution of 40 foxtail millet genotypes into different clusters

\begin{tabular}{|l|l|l|l|}
\hline S. No. & Cluster No. & No. of genotypes & Genotypes included \\
\hline $\mathbf{1 .}$ & Cluster - I & 20 genotypes & ISE 1059, ISE49, ISE 1629, ISE1820, ISE1254, ISE1234, ISE 1312, ISE 196, ISE \\
\hline $\mathbf{2 .}$ & Cluster-II & 11 Genotypes & ISE 751, ISE 969, ISE 1789, ISE 907, ISE90, ISE842, ISE 1400, ISE840, ISE96, ISE931 and ISE1419 \\
\hline $\mathbf{3 .}$ & Cluster -III & 3 Genotypes & ISE 1408, ISE 1332 and ISE1335 \\
\hline $\mathbf{4}$ & Cluster -IV & 1 Genotypes & ISE 1881 \\
\hline $\mathbf{5}$ & Cluster -V & 1 Genotypes & ISE 1474 \\
\hline $\mathbf{6}$ & Clucter -VI & 1 Genntvnes & ISF 107 \\
\hline $\mathbf{7}$ & Cluster -VII & 1 Genotypes & ISE 1888 \\
\hline $\mathbf{8}$ & Cluster -VIII & 1 Genotypes & ISE 710 \\
\hline $\mathbf{9}$ & Cluster -IX & $\mathbf{1}$ Genotypes & ISE 1541 \\
\hline
\end{tabular}


Table.4 Cluster mean value for 13 characters in foxtail millet genotypes

\begin{tabular}{|c|c|c|c|c|c|c|c|c|c|c|c|c|c|}
\hline $\begin{array}{l}\text { Characters } \\
\text { Cluster }\end{array}$ & $\begin{array}{c}\text { Days to } 50 \% \\
\text { flowering }\end{array}$ & $\begin{array}{l}\text { No of days } \\
\text { to maturity }\end{array}$ & $\begin{array}{c}\text { Plant } \\
\text { height } \\
(\mathrm{cm})\end{array}$ & $\begin{array}{l}\text { Panicle } \\
\text { length } \\
\text { (cm) }\end{array}$ & $\begin{array}{l}\text { Flag } \\
\text { leaf } \\
\text { length } \\
(\mathrm{cm})\end{array}$ & $\begin{array}{c}\text { Peduncle } \\
\text { length }(\mathrm{cm})\end{array}$ & $\begin{array}{l}\text { Leaf width } \\
\quad(\mathrm{cm})\end{array}$ & $\begin{array}{l}\text { No. of } \\
\text { basal } \\
\text { tillers }\end{array}$ & $\begin{array}{l}\text { Inflorescence } \\
\text { width } \\
\text { (cm) }\end{array}$ & $\begin{array}{l}\text { Biological } \\
\text { yield }\end{array}$ & Test weight & $\begin{array}{l}\text { Harvest } \\
\text { index }\end{array}$ & $\begin{array}{c}\text { Grain } \\
\text { yield } \\
(\mathrm{g})\end{array}$ \\
\hline Cluster 1 & 48.4 & 81.4 & 99.84 & 10.59 & 23.21 & 9.94 & 0.83 & 5.71 & 1.65 & 13.13 & 1.59 & 14.31 & 1.88 \\
\hline Cluster 2 & 59.91 & 92.91 & $\begin{array}{c}111.3 \\
7\end{array}$ & 12.4 & 22.89 & 8.39 & 0.96 & 7.1 & 2.02 & 16.8 & 2.49 & 36.06 & 6 \\
\hline Cluster 3 & 43.33 & 76.33 & 95.18 & 9.93 & 21.39 & 10.59 & 0.82 & 10.09 & 1.22 & 12.49 & 1.27 & 12.57 & 1.58 \\
\hline Cluster 4 & 51.33 & 87.33 & $\begin{array}{c}100.2 \\
3\end{array}$ & 11.63 & 24.73 & 8.03 & 1.03 & 4.73 & 3.83 & 12.87 & 1.13 & 10.45 & 1.33 \\
\hline Cluster 5 & 50 & 83 & $\begin{array}{c}121.9 \\
7\end{array}$ & 9.27 & 28.03 & 11.8 & 1.09 & 1.6 & 1.97 & 14.33 & 1.87 & 16.93 & 2.43 \\
\hline Cluster 6 & 57.67 & 90.67 & $\begin{array}{c}117.2 \\
7\end{array}$ & 10.87 & 25.87 & 9.17 & 0.94 & 5 & 3.8 & 16.8 & 1.23 & 13.89 & 2.33 \\
\hline Cluster 7 & 60.67 & 95 & 89.83 & 15.63 & 28.63 & 9.07 & 1.83 & 5.53 & 1.45 & 12.6 & 1.5 & 13.05 & 1.65 \\
\hline Cluster 8 & 53.67 & 86.67 & $\begin{array}{c}107.5 \\
3\end{array}$ & 13.27 & 24.27 & 6.5 & 1.06 & 15.93 & 1.9 & 14.8 & 1.83 & 13.17 & 1.95 \\
\hline Cluster 9 & 78 & 111 & 139 & 12.8 & 45.8 & 15.3 & 1.43 & 4 & 4.28 & 16.93 & 2.5 & 24.7 & 4.18 \\
\hline
\end{tabular}

Table.5 Intra and inter cluster distance in foxtail millet genotypes

\begin{tabular}{|c|c|c|c|c|c|c|c|c|c|}
\hline & Cluster 1 & Cluster 2 & Cluster 3 & Cluster 4 & Cluster 5 & Cluster 6 & Cluster 7 & Cluster 8 & Cluster 9 \\
\hline Cluster 1 & 131.39 & 389.07 & 219.55 & 213.37 & 213.99 & 298.5 & 215.56 & 659.01 & 595.98 \\
\hline Cluster 2 & & 168.84 & 531.78 & 563.92 & 363.24 & 338.37 & 427.9 & 657 & 354.51 \\
\hline Cluster 3 & & & 82.31 & 354 & 571.43 & 541.17 & 307.09 & 293.96 & 969.1 \\
\hline Cluster 4 & & & & 0 & 288.84 & 178.64 & 308.24 & 809.42 & 481.62 \\
\hline Cluster 5 & & & & & 0 & 219.59 & 237.76 & 1160.62 & 324.41 \\
\hline Cluster 6 & & & & & & 0 & 437.28 & 823.6 & 210.93 \\
\hline Cluster 7 & & & & & & & 0 & 686.4 & 527.73 \\
\hline Cluster 8 & & & & & & & & 0 & 1142.91 \\
\hline Cluster 9 & & & & & & & & & 0 \\
\hline
\end{tabular}


Table.6 Percent contribution of 13 characters to genetic divergence

\begin{tabular}{|c|l|c|c|}
\hline Source & Characters & $\begin{array}{c}\text { Contribution } \\
\mathbf{\%}\end{array}$ & Times ranked 1st \\
\hline $\mathbf{1}$ & Days to 50\% flowering & 1.28 & $\mathbf{1 0}$ \\
\hline $\mathbf{2}$ & No of days to maturity & 0 & $\mathbf{0}$ \\
\hline $\mathbf{3}$ & Plant height & 0 & $\mathbf{0}$ \\
\hline $\mathbf{4}$ & Panicle length & 0 & $\mathbf{0}$ \\
\hline $\mathbf{5}$ & Flag leaf length & 0 & $\mathbf{0}$ \\
\hline $\mathbf{6}$ & Peduncle length & 0 & $\mathbf{0}$ \\
\hline $\mathbf{7}$ & Leaf width & 0.13 & $\mathbf{1}$ \\
\hline $\mathbf{8}$ & No. Of basal tillers & 9.49 & $\mathbf{7 4}$ \\
\hline $\mathbf{9}$ & Inflorescence width & 15.13 & $\mathbf{1 1 8}$ \\
\hline $\mathbf{1 0}$ & Biological yield & 15.13 & $\mathbf{1 1 8}$ \\
\hline $\mathbf{1 1}$ & Grain yield & 35.26 & $\mathbf{2 7 5}$ \\
\hline $\mathbf{1 2}$ & Harvest index & 6.15 & $\mathbf{4 8}$ \\
\hline $\mathbf{1 3}$ & Test weight & $\mathbf{1 7 . 4 4}$ & $\mathbf{1 3 6}$ \\
\hline
\end{tabular}

Fig.1 Clustering of 40 foxtail millet genotypes by Tocher's Method

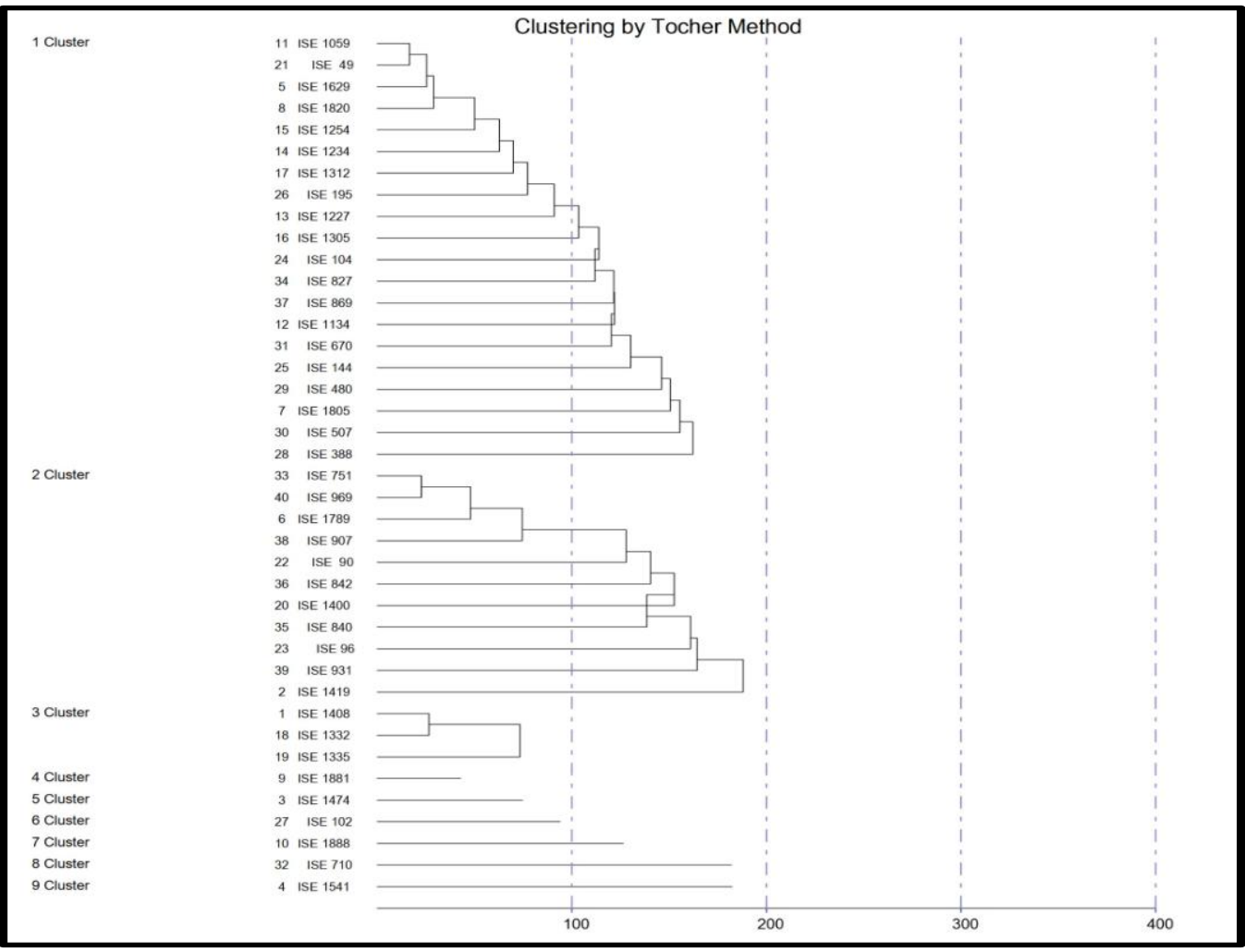


Fig.2 Intra and inter cluster distance in foxtail millet genotypes

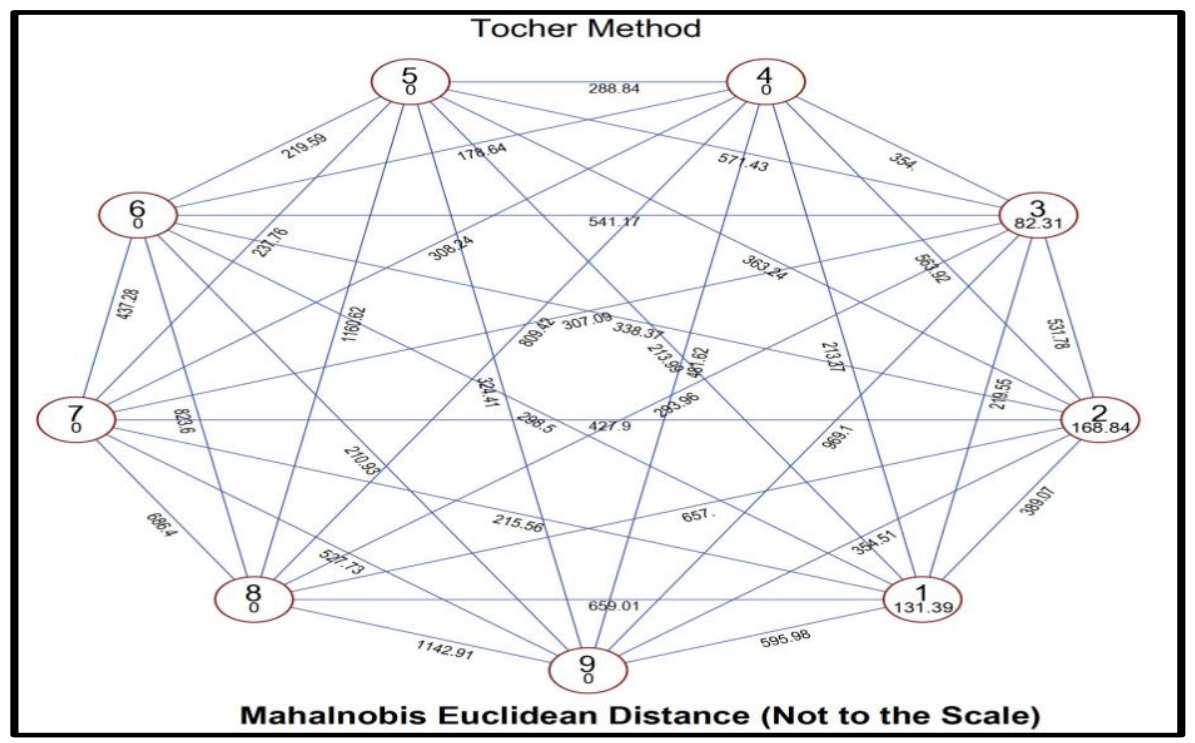

Fig.3 Percent contribution of 13 characters to genetic

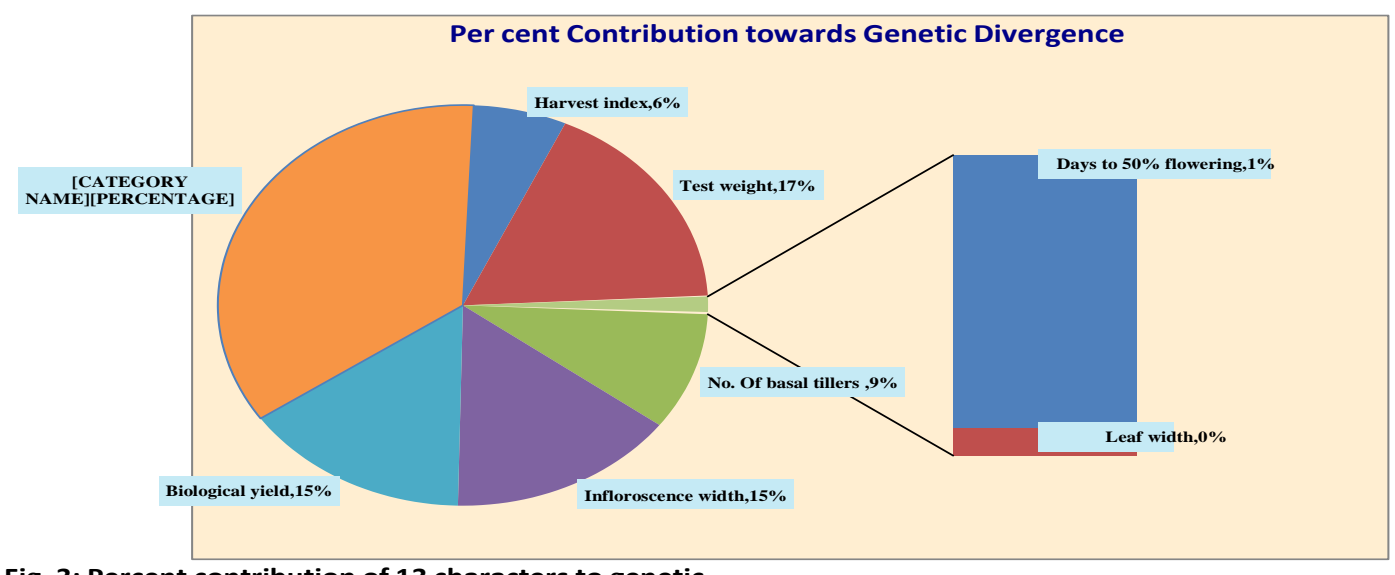

Fig. 3: Percent contribution of 13 characters to genetic

Genetic advance as percent mean (5\%) revealed highest values for all 12 characters expect for plant height which showed moderate estimate of genetic advance as percent mean.

High heritability coupled with high genetic advance as per mean (>20) were recorded for harvest index (96.7 and 107.4), test weight (97.3 and 69.9), inflorescence width (98.1 and 88.4), peduncle length (61.2 and 55.7), leaf width $(95,4$ and 53.1), number of basal tillers(99.2 and 89.9), days to $50 \%$ flowering
(92.5 and 44.1), flag leaf length (76.1 and 41.7), biological yield (98.6 and 29.1), grain yield (98 and 131.7), number of days to maturity (91.9 and 27.0)

Low heritability coupled with moderate genetic advance as per mean $(>10$ and $<20)$ was recorded for plant height (27.10 and 11.6), suggests that both additive and nonadditive gene action in their inheritance. Similar findings were reported by Ulaganathan and Nirmalakumari (2011) and Karad and Patil (2013). 
The 40 genotypes under study were grouped into nine clusters using Mahalanobis D2 analysis. The maximum number of genotypes was included in cluster I with 20 genotypes, followed by cluster II with 11 genotypes, cluster III with 3 genotypes and remaining each clusters IV, V, VI, VII, VIII, IX with one genotype each.

The average intra cluster distances ranged from (0.00 to 168.84) The maximum intracluster (D2) was registered for, cluster 2 (168.84) followed by cluster I (131.39), Cluster 3 (82.31). the minimum intra cluster recorded for cluster IV-IX (0.00).

The inter-cluster distance (D2) was found maximum between cluster $\mathrm{V}$ and cluster VIII (1160.62) followed the distance between cluster VIII and cluster IX (1142.91). The minimum inter-cluster distance was observed between cluster IV and VI (178.6). The genetic mean divergence with cluster II recorded highest valve for grain yield (6g) and harvest index (36.0) followed by cluster ix shows high values days to $50 \%$ flowering (78), number of days to maturity (111), plant height (139), flag leaf length (45.8), biological yield (16.9), test weight (2.5), therefore the genotypes included in these clusters can be utilized in crossing programmes to enhance yield.

The highest contribution in the manifestation of genetic divergence was exhibited by grain yield (35.2\%), test weight (17.4\%), inflorescence width $(15.1 \%)$, biological yield (15.13\%), number of basal tillers (9.49\%), harvest index $(6.15 \%)$, days to $50 \%$ flowering $(1.28 \%)$, leaf width $(0.13 \%)$.

It is concluded that genotype ISE1419 followed by ISE 90,ISE96, ISE751, ISE907 and ISE 969 were found superior grian yield per plant and other quantitative characters, under Prayagraj agro-climatic conditions.
The cluster V and VIII followed by cluster VIII and IX were found more diverse to each other. Genotypes present in these clusters are supposed to provide a broad spectrum of variability for grain yield upon hybridization. Therefore, it will be desirable to use these divergent parents for future hybridization program in order to obtained new transgressive segregants.

\section{References}

Anuradha N and Patro TSSK, 2019. Genetic variability, heritability and genetic advance in foxtail millet breeding lines. International Journal of Chemical Studies 2019; 7(3): 2967-2969

Arya Rinkey, Kumar Vineet and Singh Meghana, 2018. Assessment of genetic variability and heritability of grain yield components in barnyard millet (Echinochloa frumentacea (Roxb.) Link) germplasm

Ayesha Md, D. Ratna Babu, Dayal J. Prasad Babu and V. Srinivasa Rao, 2019. Studies on Correlation and Path Analysis for Grain Yield and Quality Components in Foxtail Millet [Setaria italica (L.) Beauv.]. International Journal on Current Microbiology Applied Science (2019) 8(4): 2173-2179

Brunda S. M, Kamatar M.Y, Naveenkumar K.L and Ramaling Hundekar, (2017). Study of Genetic Variability, Heritability and Genetic Advance in Foxtail Millet in both Rainy and Post Rainy Season. IOSR Journal of Agriculture and Veterinary Science (IOSR-JAVS)

Brunda S. M, Kamatar M.Y, Naveenkumar K.L and Ramaling Hundekar, 2014. Study of Genetic Variability, Heritability and Genetic Advance in Foxtail Millet in both Rainy and Post Rainy Season. IOSR Journal of Agriculture and Veterinary Science (IOSR-JAVS) II Ver III PP 3437. 
Brunda, S. M., Kamatar, M.Y., Naveenkumar, K. L., Hundekar, R. and Sowmya H.H, 2015. Research Paper Evaluation of Foxtail Millet

Dhanalakshmi TN, Ramesh S, Ravishankar CR, Upadhyaya HD, Mohan Rao A, Gangappa E, Jayarame Gowda and Priyadarshini SK, 2013. Genetic variability for morpho-agronomic traits in core germplasm collections of finger millet (Eleusine coracana (1.) Gaertn). Global Journal of Biology, Agriculture and Health Sciences., Vol.2 (2) 2013:8385

Dhedhi K, Ansodariya V V, Chaudhari N. N., Sanghani J. M. and Sorathiyal J. S, 2016. Genetic Variability and Correlation Coefficient for Fodder Yield and its Components in Forage Pearl Millet Hybrids under Rainfed Conditions of Gujarat. International Journal of Bioresource and Stress Management 2016, 7(5):970-977

Geethanjali S and Jegadeeswaran M, 2016. Genetic diversity and variability in Foxtail millet [Setaria italica (L.)] germplasm based on morphological traits. Electronic Journal of Plant Breeding, 7 (2): 303-316.

Jyothsna S, Patro T.S.S.K, Ashok S, Sandhya Y. Rani and Neeraja B, 2016. Studies on Genetic Parameters, Character Association and Path Analysis of Yield and its Components in Finger Millet (Eluesine coracana L. Gaertn). International Journal of Theoretical \& Applied Sciences, 8(1): 25-30

Kana Ram Kumawat, NK Sharma and
Nemichand Sharma, 2019. Genetic variability and character association analysis in pearl millet single cross hybrids under dry conditions of Rajasthan. Electronic Journal of Plant Breeding, 10 (3): 1067 - 1070

Mahanthesha M, Sujatha M, 2017. Studies on Variability, Heritability and Genetic Advance for Quantitative Characters in Finger millet [Eleusine coracana (L.) Gaertn.] Germplasm. International Journal of Current Microbiology and Applied Sciences, 6 (6):606-113

Manjunath H, Jayarame G, Mallikarjun K, Basavaraja T and Vijayakumar L, 2013. Genetic diversity assessment for yield and its attributing characters of white seeded accession in finger millet (Eleusine coracana (L.) Gaertn.). Environment and Ecology, 31 (2A): 740744.

Negi S, Kumar V and Bhatt A, 2017. Genetic Diversity among Finger Millet [ Eleusine coracana (L.) Gaertn] Genotypes for Yield and Its Contributing Traits. International Journal of Current Microbiology and Applied Sciences, 6 (8): 3332-3337.

Patel S N and Patil H E, 2018. Genetic Variability Study in Little Millet (Panicum miliare L.) Genotypes in Relation to Yield and Quality Traits Associate Research Science. International Journal of Current Microbiology and Applied Science, 6 (7).

Rai M, 2002. Nutritive cereals. In: Survey of Indian Agriculture, The Hindu, Chennai, Tamil Nadu, India, pp. 59-62 (2002).

\section{How to cite this article:}

Venkatesh, R., N. Lakshmi Pallavi, B. Jalandar Ram and Suresh, B. G. 2020. Genetic Divergence Analysis in the Foxtail Millet (Seteria italica) Germplasm as Determined by Phenotypical Traits. Int.J.Curr.Microbiol.App.Sci. 9(12): 1119-1127. doi: https://doi.org/10.20546/ijcmas.2020.912.135 